\title{
Zvērināta advokāta orderis kā tiesību elements
}

\author{
Linda Reisa \\ Rīgas Stradiña universitāte, Juridiskā fakultāte \\ Tiesību zinātñu katedra, Latvija \\ linda.reisa@advokatam.lv
}

\section{Kopsavilkums}

Judikatūrā ir noteikts, ka zvērinātam advokātam kā tiesu sistēmai piederīgas profesijas pārstāvim juridiskās palīdzības sniegšanai pietiek ar vienkāršu rakstveida pilnvaru, kurai papildus jāiesniedz orderis, un ka zvērinātu advokātu orderis apliecina ne vien pašu pilnvarojumu, bet arī tiesu sistēmai piederīgās personas - zvērināta advokāta ipašo statusu.

Tomēr profesionāḷu vidū jau tiek diskutēts par atteikšanos no ordera kā advokāta lietvedības dokumenta, tāpēc nav saprotams, ko judikatūra atrisina praksē, nosakot, ka civilprocesā zvērināta advokāta pilnvarojumu apliecina pilnvara un orderis. Tieši pretēji, līdz šim nebija kāzusu par to, kad un kāpēc jāiesniedz orderis. Savukārt tiesa, iespējams, šobrīd ir paudusi neuzticību advokātu institūtam, nepamatoti norādot, ka advokātu var identificēt pēc izsniegtā ordera, nevis publiskiem aktiem, tādējādi faktiski neatzīstot to par tiesu sistēmai piederīgu personu.

Atslēgvārdi: advokāts, orderis, pilnvara.

\section{levads}

Pirmās Latvijas brīvvalsts laika zvērināts advokāts Jūlijs Šmits ir teicis:

"Advokatūra, izpildīdama noteiktas tiesu organizācijas funkcijas un būdama par tiesu iekārtas nepieciešamu sastāvdaḷu, līdz ar to izpilda svarīgu uzdevumu. To nevajag aizmirst, kad novērtē advokatūras lomu valstī, kad spriež par advokatūras reorganizāciju un kad sabiedrībā pārrunā advokātu tikumus un netikumus." [9, 3]

Saskan̄ā ar Latvijas Republikas Advokatūras likuma (turpmāk - arī Advokatūras likums) 2. pantu advokatūra ir tiesiskas valsts justīcijas neatṇemama sastāvdaḷa. Savukārt šā likuma 5. pantā paredzēts, ka zvērināti advokāti (turpmāk - arī advokāti) ir tiesu 
sistēmai piederīgas personas lietu vešanai jebkurā Latvijas Republikas tiesā un pirmstiesas izmeklēšanas iestādē pēc pušu, apsūdzēto un citu lietas dalībnieku (klientu) izvēles un viṇu uzdevumā [6].

Ievērojot iepriekš minēto, kā arī Advokatūras likuma 48. panta otro punktu, likumdevējs ir noteicis, ka, sniedzot juridisko palīdzību, zvērināts advokāts ir tiesīgs vākt pierādījumus, pieprasìt visus juridiskās palīdzības sniegšanai nepieciešamos dokumentus no valsts un pašvaldību institūcijām, kā arī no citām iestādēm, organizācijām un uzṇēmējsabiedrībām (uzṇēmumiem), kurām likumā noteiktajā kārtībā un gadījumos jāizsniedz šie dokumenti vai to noraksti un zvērinātam advokātam jānodrošina iespēja iepazīties ar tiem. Saskaṇā ar Advokatūras likuma 6., 10. un 48. pantu advokātam ir piešḳirtas tiesības piekḷūt ierobežotas pieejamības informācijai, kas nepieciešama pilnvērtīgai un savlaicīgai klienta likumisko interešu aizsardzībai jebkurā procesa stadijā [6].

Neatkarīgi no tā, vai zvērinātu advokātu nolīdzis indivīds, korporācija vai valsts, viṇa būtība ir pārstāvēt klientu un būt viṇam par uzticamu padomdevēju, būt par trešo pušu respektētu profesionāli un neaizstājamu dalībnieku taisnīgas tiesas spriešanā. Ietverot visus šos elementus, zvērināts advokāts, kurš patiesi rīkojas sava klienta interesēs un aizstāv klienta tiesības, pilda arī zvērināta advokāta amatpienākumus sabiedrībā, t. i., rīkojas, lai novērstu un atturētu no konflikta, nodrošinātu, lai konfliktsituācijas tiktu risinātas saskaṇā ar atzītiem civiltiesību, valsts tiesību vai krimināltiesību principiem un ar pienācīgu tiesību un interešu ievērošanu, veicinātu tiesību pilnveidošanu un aizstāvētu brīvību, taisnīgumu un likuma varu [4].

Satversmē un Civilprocesa likumā būtiski atšḳiras jēdziena "advokāts" saturs. Satversmē tiek pieḷauts terminu "advokāts" interpretēt paplašināti, ar to saprotot ne tikai tās personas, kas ir noteiktas Advokatūras likuma 4. pantā, bet arī citus juridisko pakalpojumu sniedzējus. Proti, Satversmes 92. panta ceturtajā teikumā ir noteikts, ka "ikvienam ir tiesības uz advokāta palīdzību". Juridiskais jēdziens "advokāts", kas ietverts Satversmes 92. pantā, jātulko paplašināti, ar to saprotot personas tiesības saṇemt juridisko palīdzību, brīvi izvēloties aizstāvi vai pārstāvi dažādās lietās no iespējami plašāka kvalificētu juristu loka un atsevišşos likumā noteiktos gadījumos arī no citu personu loka [8].

Latvijas Republikas Satversmes tiesas spriedumā lietā Nr. 2003-04-01 teikts:

\footnotetext{
“Tiesības uz advokātu Satversmes 92. panta izpratnē, pirmkārt, ietver tiesības uz kvalificētu juridisko palīdzību un, otrkārt, valsts pienākumu šādu palīdzību sniegt personām, kuras pašas nevar to atḷauties. [..] Šāds no Satversmes 92. panta izrietošais ikvienas personas tiesību uz advokāta palīdzību saturs nav izsmeḷošs, tas var tikt paplašināts, bet ne ierobežots." [7]
}

Latvijas Republikas Augstākās tiesas Civillietu departaments, paplašinātā sastāvā skatot civillietas Nr. C29539915 materiālus (SKC-1788/2016), savā lēmumā (turpmāk arī - lēmums) ir norādījis, ka zvērinātu advokātu orderis apliecina ne vien pašu pilnvarojumu, bet arī tiesu sistēmai piederīgās personas - zvērināta advokāta - ipašo statusu, un ka likums papildus neaizliedz zvērinātam advokātam, tāpat kā jebkurai citai fiziskai 
personai, rīcības brīvību noslēgt pilnvarojuma līgumu Civillikuma 2289. panta izpratnē un darboties saskaṇā ar to arī ārpus viṇa profesionālās darbības ietvariem, ko regulē Advokatūras likuma normas. Tomēr tiesai visos gadỉjumos jāspēj pārliecināties, vai konkrētajā lietā attiecīgais pilnvarnieks darbojas privātpersonas vai tiesu sistēmai piederīgas personas - zvērināta advokāta - statusā [11].

Šeit minētajam nevar piekrist, jo advokāta statusu un piederību kolēgijai apliecina Zvērinātu advokātu padome atbilstoši Latvijas Republikas Advokatūras likuma noteikumiem, šie lēmumi ir publiski, tātad ieguvuši publiska akta spēku. Orderis nav pamats apliecinājumam, ka persona ir zvērināts advokāts, tas vien norāda uz sniedzamās juridiskās palīdzības apjomu un institūciju, tātad faktiski orderis jāsaista tikai ar lietas vešanas kārtību vai apjomu, nevis personas piederību Zvērinātu advokātu kolēgijai.

Latvijas Republikas Augstākā tiesa (turpāk - AT) jau ir skatījusi jautājumu par ordera nozīmi advokāta pārstāvībā civilprocesā, tomēr joprojām nav vienotas nostājas šajā jautājumā. To apliecina ne tikai AT Civillietu departamenta tiesnešu I. Gardas, V. Jonikāna, V. Maksimova un Z. Pètersones izteiktās atsevišķās domas par 2016. gada 17. jūnija lēmumu civillietā Nr. C29539915 [10], tādējādi apstiprinot, ka radītā judikatūra nav viennozīmīga, bet arī fakts, ka tiesas pilnvarojuma apjomu advokātam tulko dažādi.

Pēc autores domām, ordera institūtu būtu nepieciešams vērtēt civiltiesību nozares tvērumā.

Šã raksta mērḳis ir izpētìt ordera kā likumā noteiktā zvērināta advokāta lietvedības dokumenta jēgu un lietošanas robežas. Mērķa sasniegšanai tika izmantotas vairākas metodes: analīze, lai noskaidrotu pētāmā objekta struktūru; logiiskā metode, ar kuras palīdzību iegūtie rezultāti tika novērtēti; interpretācijas metode, lai analizētu tiesību normas. Pētījuma bāze ir dažādu zinātnieku un speciālistu atziṇas un viedokḷi, tiesu prakse, kā arī izpētē gūtie secinājumi.

\section{Rezultāti}

Saskaṇā ar Civilprocesa likuma 82. panta ceturto daḷu lietas dalībnieku piedalīšanās civilprocesā neatṇem viṇiem tiesības uzaicināt savā lietā advokātu juridiskās palīdzības sniegšanai. Šajā gadījumā advokāta pilnvaru apjoms noteikts atbilstīgi Civilprocesa likuma 86. pantam, un paskaidrojumus par lietas būtību vin,š nesniedz [3]. Savukārt saskaṇā ar Advokatūras likuma 48. ${ }^{1}$ pantu zvērināta advokāta pilnvarojumu un tā apjomu, kā arī tiesības izpildīt Advokatūras likuma 48. pantā noteiktos uzdevumus apliecina orderis, kura paraugu apstiprina Latvijas Zvērinātu advokātu padome [6].

Advokatūras likuma 48. pantā likumdevējs precīzi ir uzskaitīis tos uzdevumus, kurus advokāts ir tiesīgs izpildīt, pamatojoties uz paša izrakstītu orderi, proti:

- aizstāvēt un pārstāvēt personu, kura lūgusi juridisko palīdzību, tās tiesības un likumiskās intereses visās tiesās, prokuratūrās un pirmstiesas izmeklēšanas iestādēs, kā arī visās valsts un pašvaldỉbu institūcijās, kā arī citās iestādēs, organizācijās un uzṇēmējsabiedrībās (uzṇēmumos); 
- vākt pierādījumus, arī pieprasot visus juridiskās palīdzības sniegšanai nepieciešamos dokumentus no valsts un pašvaldību institūcijām, kā arī citām iestādēm, organizācijām un uzṇēmējsabiedrībām (uzṇēmumiem), kurām likumā noteiktajā kārtībā un gadījumos ir jāizsniedz šie dokumenti vai to noraksti un jānodrošina advokātam iespēja iepazīties ar tiem, kā arī likumā noteiktajā kārtībā juridiskās palīdzības sniegšanai saṇemt lietpratēju atzinumu jautājumos, kuri prasa attiecīgas zināšanas;

- iepazīties ar valsts un pašvaldību institūciju, tiesu, prokuratūru un pirmstiesas izmeklēšanas iestāžu normatīvajiem un individuālajiem aktiem, ar citu informāciju, kas saistīta ar juridiskās palīdzības sniegšanu, kā arī saṇemt šo dokumentu norakstus [6].

Tātad gadījumā, ja advokāts ar klientu vienojas par plašāku pilnvarojuma apjomu, klients zvērinātam advokātam izsniedz pilnvaru, kas saskaṇā ar Civilprocesa likuma 86. pantu [3] un Civillikuma 2289. pantu [2] ietver arī Advokatūras likuma 48. pantā [6] minētās tiesības. Šobrīd tiesa, nostiprinot judikatūrā pienākumu advokātam pilnvarojuma apjomu pierādìt gan ar pilnvaru, gan ar orderi, nepamatoti un mākslīgi dublē pilnvarojuma apjomu.

Var secināt, ka tiesa ar lēmumu centusies noteikt zvērināta advokāta statusa atšḳiršanu no citām personām, kas var būt par pilnvarnieku lietā, tomēr tas nav izdevies, un lēmumā sniegtajai argumentācijai nevar piekrist šādu apsvērumu dēḷ:

- orderis apliecina advokāta tiesības sniegt klientam juridisko palīdzību, taču to nevar uzskatìt par pilnvaru Civillikuma izpratnē, jo to nav izsniedzis klients, bet advokāts sev izrakstīis pats;

- orderī netiek iekḷauts pilnvarojuma apjoms, un tas nepiešḳir advokātam Civilprocesa likumā noteiktās pārstāvja tiesības, bet apliecina faktu, ka advokāts sniedz juridisko palīdzību apjomā, kas noteikts Advokatūras likuma 48. pantā.

Var uzskatìt, ka orderis pēc būtības ir speciāls uzdevums ierobežotu darbību veikšanai un tam nevajag klienta izsniegtu rakstveida vai mutvārdu pilnvarojumu. Piemēram, uz ordera pamata advokāts var pieprasìt informāciju par savu klientu, savukārt juristam, kas nav advokāts, šāda iespēja ir tikai uz notariāli apliecinātas pilnvaras pamata. Šì, iespējams, arī ir vienīgā nianse, kas ḷāvusi orderim kā tikai advokāta lietvedības dokumentam saglabāties līdz mūsdienām.

Tiesa lēmumā nepareizi ir tulkojusi Civilprocesa likuma 85. panta trešo daḷu, proti, saskaṇā ar minēto normu advokāta pilnvarojumu juridiskās palīdzības sniegšanai apliecina orderis, ja advokāts uzstājas kā puses pilnvarots pārstāvis, un šo pilnvarojumu apliecina ar rakstveida pilnvaru. Tulkojot gramatiski, redzams, ka likumdevējs ir paredzējis divas iespējas, kā advokāts pārstāv personu civilprocesā. Likumdevējs nav noteicis, kuros gadījumos jāiesniedz abi dokumenti, kuros - pietiek tikai ar vienu. Taču šì norma nelıauj nešaubīgi uzskatīt, ka orderis ir pilnvarojumu apliecinošs dokuments.

Arī doktrīnā ir pausts viedoklis, ka ir atšķirīgas prasības, kurām jāatbilst pilnvarai pārstāvēt, ko realizē advokāts vai cita persona. Advokātam pietiek ar rakstveida pilnvaru $[15,307]$. 
N̦emot vērā iepriekšminēto, rodas vairāki jautājumi. Vai pirms šīs neviennozīmīgās judikatūras maiṇas personām tika nodarīi zaudējumi, vai tika konstatēts, ka advokāts savas tiesības un pienākumus pilda negodprātīgi? Vai tieši orderis ir tas dokuments, kas turpmāk ḷaus tiesām pārliecināties, ka advokāts pilnvarotāja vārdā uzdevumu veic godam? Vai lēmums ir sasniedzis judikatūras pamatprincipu mērḳi?

Atškiriībā no pilnvaras orderis civilprocesā tiek izmantots, lai nošķirtu gadijjumus, kuros advokāts pārstāv klientu, no gadijjumiem, kuros advokāts sniedz tikai juridisko palīdzību (vai kriminālprocesā - ir aizstāvis; administratīvo pārkāpumu lietvedībā - pilda vēl nenoteiktākus uzdevumus). Savukārt no Satversmes tiesas lietas Nr. 2014-12-01 stenogrammas var secināt, ka ordera jēga ir formāla - advokāta statusu apliecinoša; tas līdz šim ticis izmantots kā pamats nošḳiršanai, vai izdevumus par advokāta sniegto juridisko palīdzību ir jāatlīdzina lietā zaudējušai pusei.

Jāpiekrīt Satversmes tiesas tiesnesei S. Osipovai, kas norādījusi: ja advokāts ir atpazīstams, ir lēmums par advokāta uzṇemšanu Advokātu kolēgijā, ir amata zīmes, dati par viṇu ir publiski pieejami - tas viss liek domāt, ka paša advokāta noteiktas formas apliecinājums (orderis) savu jēgu zaudē. Šo pašu mērḳi (apliecināt advokāta statusu) iespējams sasniegt arī citā veidā - ar advokāta iesniegtu apliecinājumu tiesai, piemēram, ar amata nosaukumu pirms uzvārda, kā to dara prokurori, tiesneši, notāri, tiesu izpildītāii un citas tiesu sistēmai piederīgās personas. Turklāt ordera iesniegšana un esamība lietā pati par sevi neapliecina advokāta statusu. Piemēram, ja persona ir bijusi advokāts laikā, kad notikusi pirmā tiesas sēde, turpinot lietas dalïbnieka pārstāvību citās tiesas sēdēs šajā instancē, personai var būt lietā esošs izrakstīts orderis (arī kasācijas instancei adresēts, piemēram, ja lieta jau vienreiz kasācijas instancē ir tikusi izskatīta) pat tad, ja persona darbību advokatūrā ir apturējusi vai arī kolēgija to ir atskaitījusi vai izslēgusi. Citiem vārdiem sakot, ne jau orderis apliecina advokāta statusu, bet gan Latvijas Zvērinātu advokātu padomes lēmumi, kuri turklāt ir publiski, un tieši tie nosaka tiesības un pienākumus advokātam lietot amata simbolus (amata zīmi, talāru), kā arī īstenot advokāta tiesības juridiskās palīdzības sniegšanā un aizstāvībā [18].

Gadijumi, kas apliecina, ka orderis nepierāda advokāta statusu un tiesības pildīt likumā noteiktos pienākumus, jau ir konstatēti praksē. 2018. gada 1. februārī Zemgales apgabaltiesa apelācijas kārtībā skatīja krimināllietu pēc Tukuma rajona prokuratūras prokurores apelācijas protesta, kurā norādīts, ka pēc krimināllietas izskatīšanas pirmās instances tiesā tika konstatēts, ka aizstāvim lietas izskatišanas laikā pirmās instances tiesā saskaṇā ar Latvijas Zvērinātu advokātu padomes Disciplinārlietu komisijas lēmumu bijis aizliegts pildīt advokāta pienākumus. Tātad, kaut gan lietā bija zvērināta advokāta izrakstîts orderis, advokāts nebija tiesīgs veikt apsūdzētā aizstāvību [13].

Minētais apliecina, ka nepamatota ordera statusa tulkošana var novest pie sekām, kas aizskar personas likumā noteiktās tiesības gan uz tiesu, gan uz lietas izskatīšanu saprātīgā termiṇā. Šāda situācija tiesiskā valstī nav piel̦aujama un ir antikonstitucionāla.

Satversmes tiesa savulaik ir norādījusi, ka advokāta orderis ir publisks akts, kas apliecina advokāta juridiskās palīdzības sniegšanu [9], tomēr šāds apgalvojums ir pretējs 
tam, kas nodibināts Administratīvā procesa likuma 1. panta piektajā un sestajā dạ̦ā, proti, saskaņā ar šīm normām ārējais normatīvais akts ir Satversme, likumi, Ministru kabineta noteikumi un pašvaldību saistošie noteikumi, kā arī starptautiskie līgumi un Eiropas Savienības pamatlīgumi un uz to pamata izdotie normatīvie akti. Iekšějais normatīvais akts ir tiesību akts, kuru publisko tiesību subjekts izdevis ar mērḳi noteikt savas vai sev padotas institūcijas iekšējās darbības kārtību vai izskaidrot kāda ārējā normatīvā akta piemērošanas kārtību savā darbības jomā (instrukcija, ieteikums, nolikums u. c.), turklāt, kā izriet no šĩ paša normatīvā akta 16. panta pirmās daḷas, iekšējais normatìvais akts ir saistošs tam publisko tiesību subjektam, kas šo aktu izdevis, kã arī šim publisko tiesību subjektam padotajām institūcijām. Privātpersonām iekšējais normatīiais akts nav saistošs [1]. Tādējādi var uzskatīt, ka orderis kā advokāta lietvedībā esošs dokuments var tikt izmantots tikai tam mērḳim, kas noteikts Advokatūras likuma 48. pantā.

Arī Civilprocesa likuma 82. pantā būtu jādzēš atsauce, jo, ja advokāts nepārstāv personu procesā uz pilnvaras pamata, var secināt, ka tiesu sistēmai piederīgā persona sniedz personai tikai juridisko palīdzību, un, ja apstiprinās, ka advokāta tiesības nav ierobežotas vai izbeigtas saskaṇā ar Advokatūras likuma noteikumiem, tad nekāds papildu apliecinājums juridiskās palīdzības sniegšanai nebūtu nepieciešams.

Nevienā ārējā normatīvajā aktā nav noteikta ordera aizpildī̌sanas kārtība, sekas par tā neprecīzu vai nepareizu aizpildī̌̌anu. Ordera noformēšanas noteikumi ir ietverti Atzinumā par advokāta ordera saturu [14; 18], kas apstiprināts ar Latvijas Zvērinātu advokātu padomes 2010. gada 20. decembra lēmumu Nr. 278 - tātad ar iekšēju aktu. Šo iekšējo aktu apstiprinājusi AT 2017. gada 27. jūnija lēmumā lietā Nr. C32336415; SKC-1299/2017, skaidrojot, ka Latvijas Zvērinātu advokātu padomes izdots iekšējais normatīvais akts, kurā reglamentēta advokāta ordera noformēšanas kārtība, ir saistošs ikvienam advokātam. Tajā noteikto prasību ignorēšana pakḷauj apdraudējumam pārstāvamās personas tiesības uz taisnīgu tiesu un būtiski apgrūtina tiesas pienākumu pārliecināties par advokāta statusu un tiesībām veikt procesuālās darbības izpildi, kā arī rada pamatotas šaubas par advokāta profesionalitāti un spēju nodrošināt kvalitatīvu juridisko palīdzību [12].

Šeit minētais apliecina, ka ordera kā tiesību elementa jēgas nepareiza iztulkošana un piemērošana var būt bīstama.

Advokatūras likuma 48. ${ }^{1}$ pantā noteikts, ka Latvijas Zvērinātu advokātu padome apstiprina ordera paraugu, nedodot tiesības Latvijas Zvērinātu advokātu padomei izdot ārēju normatīvo aktu, kas noteiktu ordera aizpildǐšanas kārtību. Tādējādi ordera veidlapa un tās aizpildīšanas kārtība uzskatāma par ieteikumu, nevis par regulējumu.

Jāvērtē arī speciālajā likumā, proti, Latvijas Republikas Advokatūras likuma 5. pantā, noteiktais, ka advokāti ir tiesu sistēmai piederīgas personas lietu vešanai jebkurā Latvijas Republikas tiesā un pirmstiesas izmeklēšanas iestādē pēc pušu, apsūdzēto un citu lietas dalībnieku (klientu) izvēles un viņu uzdevumā, kā arī likumā noteiktajos gadījumos tiesu priekšsēdētāju, pirmstiesas izmeklēšanas iestāžu vadītāju un Latvijas Zvērinātu advokātu padomes uzdevumā. Advokāti likuma noteiktajā kārtībā sniedz arī citu juridisko palīdzību [6]. No minētā arī izriet klienta un advokāta vienošanās autonomija. 
Savukārt, pievēršot uzmanību pilnvarojuma institūtam, AT Civillietu departamenta tiesneši pareizi norādijjuši, ka no Civilprocesa likuma izriet četri gadījumi, kuros advokāta statuss ir obligāts priekšnoteikums pilnvarojuma spēkā esībai vai īpašu tiesību izmantošanai.

1. Ja fiziskās personas pilnvara nav notariāli apliecināta. Saskaṇā ar Civilprocesa likuma 85. panta pirmo un trešo dal̦u fiziskā persona vienkāršu rakstveida pilnvaru, kas nav notariāli apliecināta, var izsniegt tikai advokātam.

2. Lietas vešanai kasācijas instances tiesā. Saskaṇā ar Civilprocesa likuma 82. panta sesto un septīto daḷu lietas kasācijas instances tiesā fiziskās personas ved pašas vai ar advokāta starpniecību, juridiskās personas - ar amatpersonu vai advokāta starpniecību.

3. Ja tiesas procesā uzvarējusī puse vēlas no zaudējušãs puses piedzìt izdevumus advokāta palīdzības samaksai (Civilprocesa likuma 44. panta pirmās daḷas 1. punkts; arī Augstākās tiesas Civillietu departamenta 2015. gada 28. augusta spriedums lietā Nr. C27130310; SKC-0187/2015).

Ja advokāts sniedz juridisko palīdzību saskaṇā ar Civilprocesa likuma 82. panta ceturto daḷu. Turklāt jānorāda, ka juridiskās palīdzības sniegšana šìs normas izpratnē nav "klasiskā" pārstāvība. Tas ir klienta dots uzdevums advokātam piedalīties tiesas procesā, savas procesuālās tiesības realizējot pašam prasītājam, atbildētājam vai trešajai personai, bet advokātam sniedzot juridiska rakstura padomus, uzdodot jautājumus citiem lietas dalïbniekiem un lieciniekiem un piedaloties tiesas debatēs. Tas nav pilnvarojums izpildìt visas (pilnvarā norādītās) procesuālās darbības lietas dalībnieka vietā un ir jānošķir no Civilprocesa likuma 82. panta otrajā daḷā, 83. pantā, 85. panta otrajā daḷa un 85. panta trešās daḷas otrajā teikumā minētā pilnvarojuma [10].

Latvijā tiek daudz runāts par advokāta procesa ieviešanu, tomēr, piemēram, šeit analizētā lēmuma pieṇemšana neveicina ne sadarbību starp tiesu un tiesai piederīgajām personām, ne sabiedrības uzticību tiesai.

Judikatūras grozišana, ja tās veikšanai nav objektīvu apstākḷu (grozījumu normatīvajos aktos u. c. iepriekšminēto apstākḷu), turklāt laikā, kad juristu vidū tiek spriests par atteikšanos no ordera advokāta lietvedībā gan tā arhaisma dẹl, gan nesaprotamās tā juridiskās dabas, izrietošo pienākumu un atbildības vai citām iestādēm saistošã spēka dēl, neveicina vienotu izpratni par tiesībām uz pārstāvību un tiesībām uz tiesu [18].

Jāuzsver, ka valsts ir veikusi tiesu sistēmas modernizēšanu, lēnām tiek ieviesta elektroniskā saziṇa tiesā, un arī iespējām pārliecināties par zvērināta advokāta statusu jāatbilst mūsdienu prasībām. Saskañā ar Advokatūras likuma 18. pantu Latvijas Zvērinātu advokātu kolēgija ir neatkarīga Latvijas zvērinātu advokātu profesionāla korporācija, kas apvieno visus Latvijā praktizējošos zvērinātus advokātus, tikai Latvijas Zvērinātu advokātu kolēgiijai ir šajā likumā noteiktās tiesības un pienākumi [6].

Var secināt, ka tikai Latvijas Zvērinātu advokātu kolẹgija var apliecināt, ka konkrētā persona ir zvērināts advokāts un tiesīgs uzn,emties normatīvajos aktos noteiktos pienākumus un ĩstenot tiesības. 
Vajag sākt diskusijas par to, kā nodrošināt personām, iestādēm un institūcijām iespēju elektroniski pārliecināties, vai persona, kas uzstājas kā zvērināts advokāts lietā, nav izslēgta no kolēgijas un vai tās darbība nav apturēta.

Situācijas var būt dažādas, un nav piel̦aujams, ka advokātu pienākums ir tādu darbību veikšana, ko neietver starp klientu un advokātu jau noslēgtā vienošanās, vienlaikus liedzot personai tiesības uz taisnīgu tiesu.

\section{Secinājumi}

1. Šobrīd var uzskatīt, ka tiek pārkāptas personas tiesības uz advokātu (vienošanās brīvība) un faktiski notiek iejaukšanās advokāta un klienta attiecībās.

2. Zvērināta advokāta statusu un piederību kolēgijai apliecina Zvērinātu advokātu padome atbilstoši Latvijas Republikas Advokatūras likuma noteikumiem, šādi lēmumi ir publiski, tātad ieguvuši publiska akta spēku. Orderis nav pamats apliecinājumam, ka persona ir zvērināts advokāts, tas vien norāda uz sniedzamās juridiskās palīdzības apjomu un institūciju, tātad orderis ir saistāms tikai ar lietas vešanas kārtību, nevis personas piederību Zvērinātu advokātu kolēgijai.

3. Orderis neapliecina advokāta pilnvarojumu civilprocesā tiesā, jo nav publisks akts, tā aizpildīšanas kārtībai nav ārēja normatīvā regulējuma, pieejams vien Zvērinātu advokātu padomes izdots "Atzinums par advokāta ordera saturu", kas nesniedz konkrētas norādes par dokumentā ierakstāmās informācijas apjomu. Likumdevējs nav sniedzis ordera definīciju, bet norādījis, ka tas dod eksluzīvas tiesības advokātam vākt pierādījumus, pieprasīt informāciju, iesniegt kasācijas sūdzību un îstenot aizstāvību. Minētais nav paplašināmi tulkojams, padarot orderi par zvērināta advokāta pilnvarojuma sastāvdaḷu. Orderi var uzskatīt par īpašu dokumentu to darbību veikšanai, kas noteiktas Advokatūras likuma 48. pantā. Savukārt to, vai advokāts uzstājas kā pilnvarotā persona tiesā, apliecina izdota pilnvara. Ja tās nav, būtu uzskatāms, ka zvērināts advokāts sniedz tikai juridisko palīdzību Civilprocesa likuma 82. pantā paredzētajā apjomā.

4. Civilprocesa likuma 85. panta trešã dạ̦a nav tulkojama paplašināti, proti, pilnvarojumu advokātam apliecina rakstveida pilnvara, kas izsniegta advokātam. Uz pilnvaras pamata zvērināts advokāts var gan pārstāvēt personu, gan sniegt juridisko palīdzību, savukārt uz ordera pamata šobrīd var sniegt tikai juridisko palīdzību. Nav pamata šādam duālismam. Orderis kā advokāta lietvedībā esošs dokuments var tikt izmantots tikai tam mērḳim, kas noteikts Advokatūras likuma 48. pantā. Arī atsauce Civilprocesa likuma 82. pantā būtu jādzēš, jo var secināt, ka gadījumā, ja advokāts procesā nepārstāv personu uz pilnvaras pamata, tiesu sistēmai piederīgā persona sniedz tikai juridisko palīdzību personai, un, ja apstiprinās, ka advokāta tiesības nav ierobežotas vai izbeigtas saskaṇā ar Advokatūras likuma noteikumiem, tad papildus kāds apliecinājums juridiskās palīdzības sniegšanai nav nepieciešams. 
5. Civilprocesa ietvaros jādiskutē par ordera lietderību un nepieciešamību vai tā turpmāko tiesisko statusu. Jāraisa diskusija par ordera aizstāšanu ar elektronisku iespēju personām un iestādēm pārliecināties par zvērināta advokāta tiesībām pildìt likumā noteiktos pienākumus un uzṇemties tiesības.

\section{Sworn Advocate's Retainer as Legal Element}

\section{Abstract}

Currently the case law states that a sworn advocate as a member of the judicial system should be given a simple written power of attorney, in addition to which a retainer is to be issued, and that the sworn advocate's retainer certifies not only the authorisation as such, but also the special nature of a person's belonging to the judicial system - sworn advocate - status.

There are now discussions among professionals about the abandonment of the retainer as a lawyer's record-keeping document. Thus, it is not clear what the case law solves in practice when determining that just a power of attorney and retainer together authorise a sworn advocate in a civil procedure. On the contrary, there have been no problems so far about when and why the retainer was to be served. The court, on the other hand, in the present situation may express a lack of confidence in the sworn advocate institution, unreasonably pointing out that a sworn advocate can be identified on the basis of a retainer issued, rather than by public law, and effectively denying it a person belonging to the judicial system.

Keywords: sworn advocate, retainer, power of attorney.

\section{Avoti un literatūra}

\section{Tiesību akti}

1. Administratīvā procesa likums: Latvijas Republikas likums: pieṇemts 25.10.2001. Latvijas Vèstnesis. 164, 14.11.2001.

2. Civillikums: Latvijas Republikas likums: pieñemts 28.01.1937. Valdības Vēstnesis. 46, 26.02.1937.

3. Civilprocesa likums: Latvijas Republikas likums: pieṇemts 14.10.1998. Latvijas Vēstnesis. 326/330, 03.11.1998.

4. Eiropas Advokāta profesijas pamatprincipu harta: pieṇemts 24.11.2006. CCBE. Iegūts no: https:// www.ccbe.eu/NTCdocument/ccbe_etikas_kodekss_15_1253625489.pdf [sk. 12.04.2018.].

5. Latvijas Republikas Satversme: Latvijas valsts likums: pieṇemts 15.02.1922. Latvijas Vēstnesis. 43, 01.07.1993.

6. Latvijas Republikas Advokatūras likums: Latvijas Republikas likums: pieṇemts 27.04.1993. Ziṇotājs. 28, 19.08.1993. 


\section{Tiesu prakse}

7. Latvijas Republikas Satversmes tiesas spriedums lietā Nr. 2003-04-01, 2003. gada 27. jūnijs. Latvijas Vēstnesis. 97(2862), 01.07.2003.

8. Latvijas Republikas Satversmes tiesas spriedums lietā Nr. 2003-08-01, 2003. gada 6. oktobris. Latvijas Vēstnesis. 138(2903), 07.10.2003.

9. Latvijas Republikas Satversmes tiesas spriedums lietā Nr. 2013-04-01, 2014. gada 7. februāris. Latvijas Vēstnesis. 30(5089), 11.02.2014.

10. Augstākās tiesas Civillietu departamenta tiesnešu Ināras Gardas, Valerijana Jonikāna, Valerija Maksimova un Zanes Pētersones atsevišḳās domas sakarā ar Augstākās tiesas Civillietu departamenta 2016. gada 17. jūnija lēmumu, lieta Nr. SKC-1788/2016.

11. Latvijas Republikas Augstākās tiesas Civillietu departamenta 2016. gada 17. jūnija lēmums, lieta Nr. SKC-1788/2016.

12. Latvijas Republikas Augstākās tiesas Civillietu departamenta 2017. gada 27. jūnija lēmums, lieta Nr. SKC 1299/2017.

13. Zemgales apgabaltiesas 2018. gada 1. februāra lēmums, lieta Nr. 11390009416.

\section{Literatūra}

14. Atzinums par advokāta ordera saturu. 2010. Latvijas Zvērinātu advokātu kolēgija. Iegūts no: http://www.advokatura.lv/uploads/A_Atzinums_par_advokata_ordera_saturu_2010_20_12_ Nr_278.doc [sk. 12.04.2018.].

15. Civilprocesa likuma komentāri. 2016. I daḷa. Aut. kol. prof. K. Torgāna zin. vad. Rīga: TNA.

16. Krastiṇa, I. 2008. Ėtiska neatkarība - mūsu zelts. Rīga: Biedrība "Latvietis".

17. Par Latvijas Zvērinātu advokātu padomes dokumentāciju (izraksts no padomes 1998. gada 28. novembra lēmuma Nr. 468). Latvijas Zvērinātu advokātu kolēgiija. Iegūts no: http://www. advokatura.lv/uploads/Par_padomes_dokumentaciju_Ordera_paraugs.doc [sk. 12.04.2018.].

18. Snipe, A., Šlitke, N. 2017. Viedoklis par advokāta ordera būtību un nozīmi. Jurista Vārds. 31.01.2017. Iegūts no: http://www.juristavards.lv/eseja/270076-viedoklis-par-advokata-orderabutibu-un-nozimi/ [sk. 12.04.2018.]. 